\title{
Exploring the Relationship Between Innovation Capability, Total Quality Management and SMEs Performance in Electric Fan Industry of Pakistan: Moderating Effect of Relational Learning
}

\author{
Uzma Haroon $^{1}$, Mohd Noor Mohd Shariff ${ }^{1} \&$ Mohd Sufli Yusof $^{1}$ \\ ${ }^{1}$ School of Business Management, Universiti Utara Malaysia, Malaysia \\ Correspondence: Uzma Haroon, PhD Scholar, School of Business Management, Universiti Utara Malaysia, \\ Malaysia.
}

Received: April 20, 2019

Accepted: May 7, 2019

Online Published: May 19, 2019

doi:10.5430/ijfr.v10n3p353

URL: https://doi.org/10.5430/ijfr.v10n3p353

\begin{abstract}
Purpose - The main objective of this paper is to simultaneously determine the moderating role of relational learning in the relationship between Innovation Capability, Total Quality Management and SMEs Performance. This study attempts to expand the insights by determining these relationships in the context of a rapidly liberalizing and developing economy; Pakistan. By conducting this research with Pakistani data, the authors can assess whether the relationship between these three strategic resources shows systematic differences to those in developed economies.

Design/methodology/approach - The authors of this study utilized the data collected through survey method in Electric Fan Industry of Pakistan. Well established scales were adopted from past research in order to measure the constructs used in the study. Structural equation modeling technique was used to test the hypotheses of the study. 239 fan manufacturing firms have been included in the sample. The authors used Smart PLS version 3 for data analysis.

Findings - The findings revealed that relational learning moderates the relationship between predictor and criterion variables. Contrary to the previous findings, no significant relationship between Innovation Capability and SME Performance was found to exist; however, there existed a positively significant relationship between total quality management and SME performance.

Research limitations/implications - Owing to the cross-sectional time frame that the study follows, it does not infer any causality. Having been limited to only fan manufacturing industry, the study calls for further research in different industry/country perspectives.

Practical implications - The study highlights policy building prospects for Pakistani government based on the principles of innovation capability and quality enhancement through collaborating with business networks and exploring the potential of relational learning to help improve overall SMEs performance.

Originality/value - This study contributes to the growing body of literature on SMEs-level innovation, TQM and relational learning in developing economies like Pakistan.
\end{abstract}

Keywords: innovation capability, total quality management, relational learning, SMEs performance

\section{Introduction}

Electrical Fan Industry in Pakistan is the primary focus of the present study as this industry has encountered the problem of dismal performance despite of great potential to grow and succeed both in domestic as well as international markets. Electric fan manufacturing comes under the category of light engineering industry and is considered among those pioneer industries that were operating at the time of Pakistan's independence in 1947. The cluster of electric fan industry is based in two famous cities of Pakistan, Gujarat and Gujranwala. Both the cities have become the production center for almost $98 \%$ of country's overall production. In the current production scenario, the cluster captures the sales of RS. 18 billion through its 10 million fans per year. This industry consists of 1200 fan manufacturers/vendors. This sector not only accommodates the domestic needs of the country but is also potentially exporting in the international market. The biggest international markets for Pakistani fans are UAE (23\%), Yemen (18\%), and Saudi Arabia (17\%) (Ahmed, Mahmud \& Hamid, 2010), while, Middle East, Central Asia and Africa also offer a huge export potential in this regard. 
Keeping in view the economic significance, the fan cluster has marked substantial growth during the previous decade, however; the growth performance of SMEs since 2011 is quite dismal (Afraz, Hussain \& Khan, 2014; Van Der Bank \& Van Der Bank, 2014; Paul, 2014; Moustafa., Tourkia \& Ramadan, 2017; Castro, 2018). Pertinent to Electrical fans exports, Pakistan's share of $\$ 40$ million in total international trade volume of $\$ 4$ billion is comparatively very smaller if matched with other countries in the region. SMEs of neighboring countries in the region like China, Singapore and Thailand have leapfrogged because of their internationally reputable brands, competitiveness, innovation, better quality and higher productivity.

Specifically, the aforementioned competencies of SMEs in China, Singapore, Thailand and other countries are the major weaknesses of SMEs in electrical fan manufacturing industry of Pakistan. There is lesser focus on developing reputable brands, firms lack innovation capabilities, quality management aspect is generally overlooked (Afraz et al., 2014; TDAP, 2011) relational ties among industry, academia and other business partners are quite poor and firms fail to respond to demands and cope with challenges of their respective business environment (Khan, 2015; Yanga \& Yenb, 2016; Alfauzan \& Tarchouna, 2017; Sai, 2017; Irbawati., Wiryokusumo \& Leksono, 2019).

Considering the perspective of the global opportunities available in electrical fan manufacturing, this study aims to examine some leading causes of dismal performance of SMEs in electrical fan manufacturing industry of Pakistan. Hence, this study intends to explore the relationship between Innovation Capability, Total Quality Management (Independent Variables) and SMEs Performance (Dependent Variable). Past literature as would be discussed in the literature review suggests that the relationship between the aforementioned variables is inconsistent and inconclusive. Therefore, this study has proposed Relational Learning as potential moderator as it is significantly correlated with the predictor variables as well as the criterion variable which justifies their inclusion in proposed framework as recommended by (Baron \& Kenny, 1986). The following section further emphasizes and elaborates literature review pertinent to the present study.

\section{Literature Review}

(Neely, Gregory \& Platts, 1995) define performance in terms of a process that quantifies the business actions of a firm leading it to accomplish its goals and objectives. Different ways in which the performance might be expressed include either the actual efficiency or effectiveness of a business action or the resultant outcome of the business action. Thus, in order to secure higher performance levels, respective goals and objectives of firm must be pursued in an efficient and effective manner as compared to its competitors.

Like other developing countries, Pakistan's economy is also largely based on SMEs (Khalique, Isa, Shaari \& Abdul, 2011). (Hussain, Farooq \& Akhtar, 2012) argued that SMEs have enormously contributed in Pakistan's economic stability and competitiveness since its independence. They are scattered throughout the country in urban as well as rural areas; in Pakistan SMEs comprise of $90 \%$ of overall economic enterprises, employing approximately $80 \%$ of non-agricultural workforce, and contributing almost 40\% of national GDP (MoF, 2014). Most of these SMEs are playing their potential role in employment growth and generation.

According to (Batool \& Zulfiqar, 2011), the Government of Pakistan has clearly included SME sector as one of the four central drivers of economic growth and development. They have further proposed that proactive, innovative and flexible SMEs can have the potential of employment creation, introduction of efficient work force, production of foreign exchange, distribution of technological knowledge and development of the business management skills throughout Pakistan, therefore, adding to the overall economic progress of the country.

Keeping in view the above mentioned discussion in relation to problems of SMEs in Pakistan, a few contemporary variables have been selected for this study in order to examine their relationship with SMEs Performance. These variables include Innovation Capability and Total Quality Management as independent variables and Relational Learning.

A detailed literature review describes that there are two dissimilar viewpoints found with regards to the relationship between innovation capability and SMEs performance. At one hand, several researchers have attempted to highlight the importance of innovation capability for greater firm performance (Bowen, Rostami \& Steel, 2010; Cainelli, Evangelista \& Savona, 2004; Calantone, Cavusgil \& Zhao, 2002; Hafeez, 2014; Hafeez, Shariff \& bin Mad Lazim, 2013; Hashi \& Stojčić, 2013; Keskin, 2006; Rhee, Park \& Lee, 2010). On the other hand, studies showing insignificant relationship between innovation capability and firm performance are also present (Armour \& Teece, 1978; Darroch, 2005; Geisser, 1974; Hage \& Aiken, 1967; Kimberly \& Evanisko, 1981; Rogers, 1995; Saunila, 2014). However, majority of the studies have exhibited a positive relationship between innovation capability and SMEs performance. For that reason, the study hypothesizes the following: 
H1: There is a positive relationship between Innovation Capability and SME Performance.

With reference to TQM and SMEs Performance relationship, most of the empirical studies which examined the impact of TQM on performance have established that implementation of TQM practices improves the firm performance (Duh, Hsu \& Huang, 2012; Gimenez-Espin, Jiménez-Jiménez \& Martínez-Costa, 2013; Kaynak \& Hartley, 2008; Kim, Kumar \& Kumar, 2012; Lam, Lee, Ooi \& Lin, 2011; Rahman \& Bullock, 2005). Therefore, TQM implementation needs to be adjusted and applied by SMEs in the same manner. Hence, this study hypothesizes that:

$\mathrm{H} 2$ : There is a positive relationship between TQM and SME Performance.

Moreover, it is suggested in the literature that relational learning of a firm can enable an organization to optimally exploit the benefits of its innovation capability (Ahuja \& Katila, 2001; Bell \& Zaheer, 2007) and TQM practices (Ahuja \& Katila, 2001; Bell \& Zaheer, 2007; Kocoglu, Imamoglu \& İnce, 2011; Loke, Downe, Sambasivan \& Khalid, 2012; Martínez-Costa, Martínez-Lorente \& Choi, 2008). Nevertheless, to the best of our knowledge there are very limited empirical studies if any that have explored the moderating effect of relational learning capability on innovation capability-performance and TQM-performance relationship in the context of SMEs.

Relational learning capability takes in to consideration the knowledge that exists outside the firm. The capability of a firm to integrate the external knowledge in their innovation capability and TQM can largely determine the performance of SMEs. Keeping in consideration the above mentioned discussion the following hypotheses are thus posited:

H3: Relational learning moderates the relationship between innovation capability and SMEs performance.

H4: Relational learning moderates the relationship between TQM and SMEs performance.

\section{Research Methodology}

This study has employed quantitative research method. Survey was conducted in Electric Fan Industry of Pakistan. SMEs owners/managers were the respondents for this study. 239 usable responses were gathered using a structured questionnaire. Scales were adopted/adapted from the previous literature. Smart PLS version 3 was used. Structural equation modeling technique was employed to test the hypotheses. Two stage process was used to test the moderating effects.

\section{Findings and Results}

Demographic profile of respondents was quite diverse in terms of age of business, firm size and capital invested in the business. Before initiating multivariate data analysis initial screening of the data was ensured to verify the suitability of the data for advanced multivariate analysis. Tests pertaining to detection of outliers, data linearity, normality, multicollinearity, homoscedasticity, and auto correlation were performed. Afterwards, Measurement Model was evaluated to verify Convergent and Discriminant validity as given in Table 1 and Table 2 respectively.

Table 1. Convergent validity

\begin{tabular}{lllll}
\hline Constructs and Indicators & Cronbach's Alpha & rho_A & Composite Reliability & AVE \\
\hline Innovation Capability & 0.982 & 0.982 & 0.983 & 0.773 \\
\hline Total Quality Management & 0.982 & 0.982 & 0.983 & 0.763 \\
\hline Relational Learning & 0.985 & 0.986 & 0.986 & 0.811 \\
\hline SMEs Performance & 0.986 & 0.986 & 0.988 & 0.870 \\
\hline
\end{tabular}

Table 2. Discriminant validity - fornell larcker criterion

\begin{tabular}{lllll}
\hline Constructs & IC & TQM & RL & SMEs Perf. \\
\hline Innovation Capability & $\mathbf{0 . 8 7 9}$ & & & \\
\hline Total Quality Management & 0.686 & $\mathbf{0 . 8 7 3}$ & & \\
\hline Relational Learning & 0.611 & 0.699 & $\mathbf{0 . 9 0 0}$ & \\
\hline SMEs Performance & 0.704 & 0.866 & 0.778 & $\mathbf{0 . 9 3 3}$ \\
\hline
\end{tabular}


After ensuring the convergent and discrimnant validity of the measurement model, structural model was constructed to test the hypotheses of the study as given below in Figure 1.

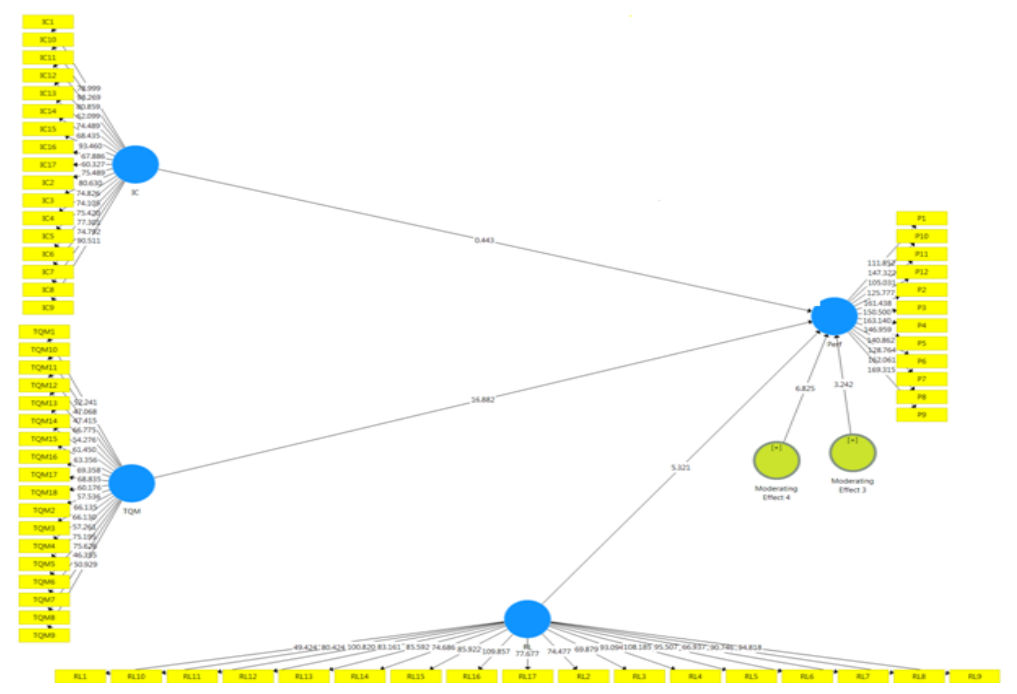

Figure 1. Structural model

Based on the corresponding T-statistics and P-values given in Table 3, it is revealed that there is no significant relationship between Innovation Capability and SME Performance; whereas, there exists a positively significant relationship between total quality management and SME performance. Moreover, results indicate that relational learning significantly moderates the relationship between Innovation Capability, TQM and SMEs Performance.

Table 3. Hypotheses testing (direct effects of IC \& TQM and moderating effects of relational learning)

\begin{tabular}{|c|c|c|c|c|c|c|c|}
\hline Hypothesis & Relationship & & $\begin{array}{l}\text { Std. } \\
\text { Beta }\end{array}$ & $\begin{array}{l}\text { Std. } \\
\text { Error }\end{array}$ & t-value & $p$-value & Decision \\
\hline H1 & $\begin{array}{l}\text { IC } \quad-> \\
\text { Performance }\end{array}$ & SMEs & 0.018 & 0.003 & 0.443 & 0.33 & Not Supported \\
\hline H2 & $\begin{array}{l}\text { TQM -> } \\
\text { Performance }\end{array}$ & SMEs & 0.737 & 0.003 & $16.882 * *$ & $0.000 * *$ & Supported \\
\hline H3 & $\mathbf{I C} * \mathbf{R L}$ & & 0.133 & 0.002 & 3.242 & $0.001 * *$ & Supported \\
\hline H4 & TQM*RL & & 0.258 & 0.003 & 6.825 & $0.000 * *$ & Supported \\
\hline
\end{tabular}

$* * \mathrm{p}<0.01$, Results are significant with 1 tail where: $\mathrm{T}$ values $>2.33$ ( $\mathrm{p}$ values $<0.01)$

$* \mathrm{p}<0.05$, Results are significant with 1 tail where: $\mathrm{T}$ values $>1.645$ ( $\mathrm{p}$ values $<0.05)$

Moreover, for the purpose of determining the strength of the moderating effects of Relational Learning on the relationship between Innovation Capability, Total Quality Management and SMEs performance, (Cohen, 2013), effect size was calculated. Furthermore, the moderating effects' strength, can be assessed by comparison between the value of R-squared (coefficient of determination) of the main effect model with that of the $R$-squared value of the full model that involves both independent variables and moderating variable (Henseler \& Fassott, 2010; Wilden, Gudergan, Nielsen \& Lings, 2013). Effect size of moderation is given below in Table 4. Results indicate strong moderating effects of relational learning on the relationship between predictor and criterion variables. 
Table 4. Effect Size of moderating variable (f ${ }^{2}($ Henseler \& Fassott, 2010) and (Cohen, 2013) recommendation

\begin{tabular}{lllll}
\hline Moderating Variable & $\mathbf{R}^{2}$ Included & $\mathbf{R}^{2}$ Excluded & f-Squared & Effect Size \\
\hline Relational Learning & 0.876 & 0.846 & 0.242 & Strong \\
\hline
\end{tabular}

Moreover, an assessment of predictive relevance serves as another measure when it comes to structural model extractions. Hence, this study applied the Stone-Geisser's test of predictive relevance research model by means of blindfolding procedures (Geisser, 1974; Stone, 1974). Similarly, (Chin, 1998) and (Hair Jr, Sarstedt, Hopkins \& Kuppelwieser, 2014) opined that $\mathrm{Q}^{2}$ is a criterion used in order to measure how well a research model predicts the omitted cases' data. In another development, (Henseler, Ringle \& Sinkovics, 2009), stated that a research model with a $\mathrm{Q}^{2}$ statistic (s) higher than zero is regarded to have predictive relevance. Predictive relevance is given in the following Table 5 .

Table 5. Construct cross-validated redundancy (predictive relevance)

\begin{tabular}{llll}
\hline Total & SSO & SSE & Q $^{\mathbf{2}}$ (1-SSE/SSO) \\
\hline Innovation Capability & $4,063.00$ & $4,063.00$ & \\
\hline Total Quality Management & $4,302.00$ & $4,302.00$ & \\
\hline Relational Learning & $4,063.00$ & $4,063.00$ & \\
\hline SMEs Performance & $2,868.00$ & 853.115 & 0.613 \\
\hline
\end{tabular}

Hence, $\mathrm{Q}^{2}$ in Table 5 shows an acceptably good relevance (0.613) for the criterion variable (SMEs Performance), indicating that the model developed for the study has high predictive relevance.

\section{Conclusion}

The study substantively contributes to the extant literature on innovation, TQM and relational learning in the context of an emerging market such as Pakistan. The study reflects policy building prospects for government of Pakistan based on the principles of innovation capability and quality enhancement through collaborating with business networks and exploring the potential of relational learning to boost the performance of SMEs. Furthermore, SMEs in Pakistan require a greater focus on adopting and sustaining TQM practices to create a distinguished management style which would enable them to compete locally as well as internationally. TQM paves the way for channelizing a quality culture and cross-functional team knowledge transfer which can shield SMEs from intense competition and can allow them to leapfrog and outperform their business rivals.

\section{References}

Afraz, N., Hussain, S. T., \& Khan, U. (2014). Barriers to the Growth of Small Firms in Pakistan: A Qualitative Assessment of Selected Light Engineering Industries. The Lahore Journal of Economics, 19, 135-176.

Ahmed, H., Mahmud, M., \& Hamid, N. (2010). A strategy for reversing Pakistan's dismal export performance. CREB Policy Paper (pp. 1-10). https://doi.org/10.2139/ssrn.1682430

Ahuja, G., \& Katila, R. (2001). Technological acquisitions and the innovation performance of acquiring firms: A longitudinal study. Strategic Management Journal, 22(3), 197-220. https://doi.org/10.1002/smj.157

Alfauzan, A. A., \& Tarchouna, N. (2017). The Role of an Aligned Curriculum Design in the Achievement of Learning Outcomes. Journal of Education and e-Learning Research, 4(3), 81-91. https://doi.org/10.20448/journal.509.2017.43.81.91

Armour, H. O., \& Teece, D. J. (1978). Organizational structure and economic performance: A test of the multidivisional hypothesis. Bell Journal of Economics, 9(1), 106-122. https://doi.org/10.2307/3003615

Baron, R. M., \& Kenny, D. A. (1986). The moderator-mediator variable distinction in social psychological research: Conceptual, strategic, and statistical considerations. Journal of Personality and Social Psychology, 51(6), 1173-1182. https://doi.org/10.1037/0022-3514.51.6.1173

Batool, S. A., \& Zulfiqar, S. (2011). The Performance and Structure of Small \& Medium Enterprises: An Empirical 
Evidence from Pakistan. Pakistan Journal of Social Sciences (PJSS), 31(2).

Bell, G. G., \& Zaheer, A. (2007). Geography, networks, and knowledge flow. Organization Science, 18(6), 955-972. https://doi.org/10.1287/orsc.1070.0308

Bowen, F. E., Rostami, M., \& Steel, P. (2010). Timing is everything: A meta-analysis of the relationships between organizational performance and innovation. Journal of Business Research, 63(11), 1179-1185. https://doi.org/10.1016/j.jbusres.2009.10.014

Cainelli, G., Evangelista, R., \& Savona, M. (2004). The impact of innovation on economic performance in services. The Service Industries Journal, 24(1), 116-130. https://doi.org/10.1080/02642060412331301162

Calantone, R. J., Cavusgil, S. T., \& Zhao, Y. (2002). Learning orientation, firm innovation capability, and firm $\begin{array}{lllll}\text { performance. } \quad \text { Industrial Marketing } & \text { Management, } & \text { 31(6), }\end{array}$ https://doi.org/10.1016/S0019-8501(01)00203-6

Castro, M. (2018). A Didactic Experiment with Cinema-Portuguese Emigration and Sense of Belonging. Global Journal of Social Sciences Studies, 4(2), 70-77. https://doi.org/10.20448/807.4.2.70.77

Chin, W. W. (1998). The partial least squares approach to structural equation modeling. Modern Methods for Business Research, 295(2), 295-336.

Cohen, J. (2013). Statistical power analysis for the behavioral sciences. Routledge.

Darroch, J. (2005). Knowledge management, innovation and firm performance. Journal of Knowledge Management, 9(3), 101-115. https://doi.org/10.1108/13673270510602809

Duh, R.-R., Hsu, A. W.-H., \& Huang, P.-W. (2012). Determinants and performance effect of TQM practices: An integrated model approach. Total Quality Management \& Business Excellence, 23(5-6), 689-701.

Geisser, S. (1974). A predictive approach to the random effect model. Biometrika, 61(1), 101-107.

Gimenez-Espin, J. A., Jiménez-Jiménez, D., \& Martínez-Costa, M. (2013). Organizational culture for total quality management. Total Quality Management \& Business Excellence, 24(5-6), 678-692.

Hafeez, M. H. (2014). Moderating effects of organizational learning capability on the relationship between innovation, branding and SMEs performance in sports industry of Pakistan. Unpublished doctoral dissertation. Universiti Utara Malaysia.

Hafeez, M. H., Shariff, M. N. M., \& bin Mad Lazim, H. (2013). Does innovation and relational learning influence SME Performance? An Empirical Evidence from Pakistan. Asian Social Science, 9(15), 204.

Hage, J., \& Aiken, M. (1967). Program change and organizational properties a comparative analysis. American Journal of Sociology, 72(5), 503-519. https://doi.org/10.1086/224380

Hair, J. Jr., Sarstedt, M., Hopkins, L., \& G. Kuppelwieser, V. (2014). Partial least squares structural equation modeling (PLS-SEM) An emerging tool in business research. European Business Review, 26(2), 106-121.

Hashi, I., \& Stojčić, N. (2013). The impact of innovation activities on firm performance using a multi-stage model: Evidence from the Community Innovation Survey 4. Research Policy, 42(2), 353-366.

Henseler, J., \& Fassott, G. (2010). Testing moderating effects in PLS path models: An illustration of available procedures Handbook of partial least squares (pp. 713-735). Springer.

Henseler, J., Ringle, C. M., \& Sinkovics, R. R. (2009). The use of partial least squares path modeling in international marketing new challenges to international marketing (pp. 277-319). Emerald Group Publishing Limited.

Hussain, I., Farooq, Z., \& Akhtar, W. (2012). SMEs development and failure avoidance in developing countries through public private partnership. African Journal of Business Management, 6(4), 1581-1589.

Irbawati, W. N., Wiryokusumo, I., \& Leksono, I. P. (2019). The Effects of Conventional Method, Mind Mapping Method, and Learning Motivation on Thematic Learning Outcomes in 3rd Grade of Elementary School. International Journal of Educational Technology and Learning, 5(1), 25-31.

Kaynak, H., \& Hartley, J. L. (2008). A replication and extension of quality management into the supply chain. Journal of Operations Management, 26(4), 468-489. https://doi.org/10.1016/j.jom.2007.06.002

Keskin, H. (2006). Market orientation, learning orientation, and innovation capabilities in SMEs: An extended model. European Journal of Innovation Management, 9(4), 396-417. https://doi.org/10.1108/14601060610707849 
Khalique, M., Isa, A. H. B. M., Shaari, N., \& Abdul, J. (2011). Challenges for Pakistani SMEs in a knowledge-based economy. Indus Journal of Management \& Social Sciences, 5(2), 74-80.

Khan, S. (2015). A pragmatic model for industry academia communication interfacing. SMEDA Research Journal, 2(1), 46-54.

Kim, D.-Y., Kumar, V., \& Kumar, U. (2012). Relationship between quality management practices and innovation. Journal of Operations Management, 30(4), 295-315. https://doi.org/10.1016/j.jom.2012.02.003

Kimberly, J. R., \& Evanisko, M. J. (1981). Organizational innovation: The influence of individual, organizational, and contextual factors on hospital adoption of technological and administrative innovations. Academy of Management Journal, 24(4), 689-713. https://doi.org/10.5465/256170

Kocoglu, I., Imamoglu, S. Z., \& İnce, H. (2011). The relationship between organizational learning and firm performance: The mediating roles of innovation and TQM. Journal of Global Strategic Management, 9(3), 72-88. https://doi.org/10.20460/JGSM.2011515814

Lam, S.-Y., Lee, V.-H., Ooi, K.-B., \& Lin, B. (2011). The relationship between TQM, learning orientation and market performance in service organisations: An empirical analysis. Total Quality Management \& Business Excellence, 22(12), 1277-1297. https://doi.org/10.1080/14783363.2011.631337

Loke, S.-P., Downe, A. G., Sambasivan, M., \& Khalid, K. (2012). A structural approach to integrating total quality management and knowledge management with supply chain learning. Journal of Business Economics and Management, 13(4), 776-800. https://doi.org/10.3846/16111699.2011.620170

Martínez-Costa, M., Martínez-Lorente, A. R., \& Choi, T. Y. (2008). Simultaneous consideration of TQM and ISO 9000 on performance and motivation: An empirical study of Spanish companies. International Journal of Production Economics, 113(1), 23-39. https://doi.org/10.1016/j.ijpe.2007.02.046

Moustafa, H., Tourkia, F. B., \& Ramadan, R. M. (2017). Application of Artificial Neural Networks Modeling for Evaluation of ELearning/Training Convergence Time. American Journal of Education and Learning, 2(2), 159-179. https://doi.org/10.20448/804.2.2.159.179

Neely, A., Gregory, M., \& Platts, K. (1995). Performance measurement system design: a literature review and research agenda. International Journal of Operations \& Production Management, 15(4), 80-116.

Paul, M. (2014). Ensuring Quality Provision of Education for All: Discovering Challenges Faced by Teachers of Students with Learning Disabilities in Regular Primary Schools in Masvingo District. International Journal of Public Policy and Administration Research, 1(1), 26-37.

Rahman, S.-U., \& Bullock, P. (2005). Soft TQM, hard TQM, and organisational performance relationships: an empirical investigation. Omega, 33(1), 73-83. https://doi.org/10.1016/j.omega.2004.03.008

Rhee, J., Park, T., \& Lee, D. H. (2010). Drivers of innovativeness and performance for innovative SMEs in South Korea: Mediation of learning orientation. Technovation, 30(1), 65-75.

Rogers Everett, M. (1995). Diffusion of innovations (Vol. 12). New York, NY: The Free Press.

Sai, F. (2017). Exploring Learning Experience in a Total Enterprise Simulation Based on Means-End Theory. International Journal of Management and Sustainability, 6(3), 54-62.

Saunila, M. (2014). Innovation capability for SME success: perspectives of financial and operational performance. Journal of Advances in Management Research, 11(2), 163-175. https://doi.org/10.1108/JAMR-11-2013-0063

Stone, M. (1974). Cross-validatory choice and assessment of statistical predictions. Journal of the Royal Statistical Society: Series B (Methodological), 36(2), 111-133. https://doi.org/10.1111/j.2517-6161.1974.tb00994.x

TDAP. (2011). Engineering Division's report on Fan Industry of Pakistan. Retrieved from http://www.tdap.gov.pk/doc_reports/tdap_report_on_fan_industry_in_pakistan.pdf

Van Der Bank, C. M., \& Van Der Bank, M. (2014). Learning Centred Environments Supporting The Environment of E-Learning in South Africa in Law Class. Humanities and Social Sciences Letters, 2(2), 93-107.

Wilden, R., Gudergan, S. P., Nielsen, B. B., \& Lings, I. (2013). Dynamic capabilities and performance: strategy, structure and environment. Long Range Planning, 46(1-2), 72-96. https://doi.org/10.1016/j.lrp.2012.12.001

Yanga, J. Y., \& Yenb, Y. C. (2016). College Students' Perspectives of E-Learning System Use in High Education. Asian Journal of Education and Training, 2(2), 53-62. 